\title{
Ku globalnemu paradygmatowi współistnienia kultur w warunkach ustawicznych migracji
}

\begin{abstract}
Streszczenie
Autor wychodzi z założenia, że problem migracji jest wpisany w rozwój człowieka i kultur. Traktując kulturę odziedziczoną jako wartość niezbywalną, podstawę pozwalającą uświadomić i kreować paradygmat współistnienia kultur, wskazuje na dominujące obecnie zasady polityki globalnej.

Uważa, że ludzie, należąc do tej samej cywilizacji globalnej, winni aktywnie uczestniczyć w procesie kreowania globalnego paradygmatu współistnienia kultur poprzez planowanie i podejmowanie działań edukacyjnych wspierających procesy adaptacji, kształtowanie świadomości w zakresie pogranicznego funkcjonowania i z tym związanych kompetencji międzykulturowych. Ostatecznym efektem w proponowanym modelu jest zrównoważony system tożsamościowy który autor postrzega i analizuje w trzech zakresach (dziedziczonym, indywidualnie kształtowanym i społecznie realizowanym), w trzech czasookresach (przeszłość, teraźniejszość, antycypowana przyszłość) i wielu wymiarach tożsamości indywidualnej (biologicznej, psychicznej, ekonomicznej, kulturowej, intelektualnej, egzystencjalnej itp.) oraz wielu wymiarach tożsamości społeczno-kulturowej (rodzinnej, familijnej, parafialnej, lokalnej, regionalnej, religijnej, etnicznej, narodowościowej, państwowej, kontynentalnej, globalnej).
\end{abstract}

1 Jerzy Nikitorowicz, Katedra Edukacji Międzykulturowej i Elementarnej, Uniwersytet w Białymstoku, Polska, e-mail: j.nikitorowicz@uwb.edu.pl, ORCID ID: https://orcid.org/00000003-4371-8322. 


\title{
Słowa kluczowe:
}

kultura, migracje, tożsamość, cywilizacja globalna, paradygmat współistnienia, pogranicze kultur

\begin{abstract}
The author assumes that the problem of migration is inscribed in the development of man and cultures. Treating inherited culture as an inalienable value, the basis for awareness and creation of the paradigm of the coexistence of cultures. Author points to the currently dominant principles of global politics.

Points out that people belonging to the same global civilization should actively participate in the process of creating a global paradigm of the coexistence of cultures by planning and undertaking educational activities supporting the adaptation processes, shaping awareness of borderland functioning and related intercultural competences. The final effect in the proposed model is a balanced identity system that the Author perceives and analyzes in three areas (inherited, individually shaped and socially realized), in three time periods (past, present, anticipated future) and many dimensions of individual identity (biological, psychological, economic, cultural, intellectual, existential, etc.) and also many dimensions of socio-cultural identity (family, parish, local, regional, religious, ethnic, national, state, continental, global).
\end{abstract}

\section{Keywords:}

culture, migrations, identity, global civilization, paradigm of coexistence, borderland of cultures

\section{ZAŁOŻENIA WSTĘPNE}

Pewne zjawiska i procesy, między innymi migracja, wpisane są w rozwój gatunku ludzkiego, kultur i cywilizacji. Migracje to stały, odwieczny element tożsamościowy towarzyszący człowiekowi poszukującemu lepszych warunków życia i rozwoju, to nadzieja na jego poprawę, na uniknięcie dezorganizacji w różnych wymiarach życia i niszczących konfliktów. Stąd zjawisko to analizowane jest w różnych kontekstach, między innymi w demograficznym, ekonomicznym, kulturowym, edukacyjnym, psychicznym, politycznym, zdrowotnym itp. W ostatnich latach szczególna mobilność związana była z globalnymi rynkami pracy, problemami ekonomicznymi, postępem technologicznym, natomiast obecnie, wobec światowej pandemii, wyraźnie odczuwalne są działania separujące obywateli w ich państwach narodowych. Czy przedłużająca się pandemia powstrzyma migracje 
i usztywni gospodarki narodowe, spowoduje rezygnację w zatrudnianiu obywateli innych krajów, czy zmniejszy migrację ekonomiczną, powstrzyma od migracji pozaekonomicznych?

Sądzę, że gatunek ludzki jest w stanie poradzić sobie z tym problemem, tak jak w przeszłości radził z wieloma innymi, które pojawiały się na naszym globie. Jednak sytuacja ta winna mobilizować gatunek ludzki do ukierunkowania działalności edukacyjnej ku paradygmatowi współistnienia kultur, który traktuję jako ideę i zarazem model funkcjonowania społeczeństw zróżnicowanych kulturowo, wartość uczącą zrozumienia, porozumienia i tolerancji, potrzebę poznawania się wzajemnego, współpracy, negocjacji i dialogu w celu zachowania i kształtowania pokojowych rozwiązań.

Jestem przekonany, że migracji nie jest w stanie nikt i nic zatrzymać, stąd za szczególnie istotne uważam kreowanie globalnego paradygmatu współistnienia kultur, planowanie i podejmowanie działań edukacyjnych wspierających procesy adaptacji, kształtowanie świadomości w zakresie pogranicznego funkcjonowania i z tym związanych kompetencji międzykulturowych, „otwieranie” reprezentantów odmiennych kultur na nowe treści, które nie muszą kolidować z paradygmatem etnicznym czy plemiennym, który polegał na reprodukowaniu przez kolejne pokolenia zamkniętego kanonu kulturowego. W tym procesie niezbędne są działania niwelujące zagrożenia i lęki przed innymi, aby doprowadzić do symetrycznej wymiany treści kulturowych. Z jednej strony funkcjonowanie migranta w odziedziczonej kulturze sprzyja identyfikacji z zasadami, wzorcami, wartościami, systemem nagród i kar czy sankcjami w niej dominującymi, z drugiej zaś, w nowych warunkach, niezbędne jest przyswojenie nowych zasad i wartości, wypracowanie zrównoważonego systemu tożsamościowego wspomagającego proces adaptacji poprzez kształtowanie obok odziedziczonej tożsamości nowego zakresu norm, wartości i wzorów. Traktując elementy kultury odziedziczonej jako wartości niezbywalne, jako podstawę pozwalającą uświadomić i kreować paradygmat współistnienia kultur, chcę zwrócić uwagę na zakresy i wymiary tożsamości związane z wychodzeniem poza własną, odziedziczoną tożsamość etniczną czy religijną, poza plemienne podziały na różne My i Oni. Jak wskazuje Z. Kawczyńska-Butrym (2009), migracje to nie tylko zmiana miejsca w przestrzeni fizycznej, to zmiana sytuacji społecznej, statusu społecznego, pozycji zawodowej i całej gamy relacji rodzinnych, familijnych i międzyludzkich. To także ustawiczne doświadczanie odmienności kulturowej i uczenie się komunikowania swoich potrzeb, reagowania na różnice kulturowe itp. Stąd teza, na której opieram swoją wypowiedź, jest przeciwstawna do znanej tezy „zderzenia cywilizacji” Samuela P. Huntingtona. W przedmowie do pracy „Zderzenie cywilizacji i nowy kształt ładu 
światowego” Huntington pisze: „(...) żaden z paradygmatów nie zachowuje aktualności po wiek wieków. Jeśli podejście uwzględniające różnorodność cywilizacji może być przydatne do rozumienia polityki światowej pod koniec XX i na początku XXI wieku, nie znaczy to, że byłoby równie użyteczne pół wieku temu albo będzie w połowie następnego stulecia” (1998, s. 7-8). Jak pisze Yuval Noah Harari (2018, s. 129): „Według tej tezy ludzkość zawsze dzieliła się na różne cywilizacje, których członkowie widzą świat na różne, niedające się pogodzić sposoby. Te rozbieżne światopoglądy powodują, że konflikty między cywilizacjami są nieuniknione”. Jednak obecnie przyjmuje się jeden polityczny paradygmat (suwerenne państwa, wspólny protokół dyplomatyczny, prawa wyborcze, prawo międzynarodowe). Zdążamy więc do fundamentalnych zasad globalnego porządku politycznego, starań o międzynarodowe uznanie. Eksperymenty z różnymi systemami politycznymi i modelami ekonomicznymi przeszły do historii i zaczęły dominować zasady globalnej polityki. Mamy więc nieznacznie różniące się systemy sprawowania rządów, teorie ekonomiczne, korporacje i trendy kapitałowe. Harari podkreśla, że zaufanie do dolara podzielają nawet islamscy fundamentaliści, meksykańscy baronowie narkotyków i północnokoreańscy tyrani. Jednorodność współczesnej ludzkości widać najwyraźniej „(...) gdy rzecz dotyczy naszych poglądów na świat przyrody i na ludzkie ciało. Gdy ktoś zachorował tysiąc lat temu, miejsce jego zamieszkania miało ogromne znaczenie. W Europie miejscowy ksiądz przypuszczalnie powiedziałby takiej osobie, że widocznie ściągnęła na siebie Boży gniew, a zatem by odzyskać zdrowie, musi złożyć ofiarę na Kościół, odbyć pielgrzymkę do jakiegoś sanktuarium i żarliwie się modlić o Boże przebaczenie” (Harari, 2018, s. 145). Z kolei w innych miejscach globu ziemskiego chorobę tłumaczono utratą równowagi między czterema podstawowymi płynami ciała (humorami), w innych trzema elementami cielesnymi itd. Obecnie lekarze korzystają z leków wyprodukowanych przez te same międzynarodowe koncerny farmaceutyczne, reprezentują podobne poglądy na temat ludzkiego ciała i chorób, a w sytuacji pandemii, z jaką mamy obecnie do czynienia, jednoczą się, aby wspierać się w działaniach poszukujących skuteczną szczepionkę. Współcześnie wykształceni ludzie rozsiani na globie ziemskim mają te same poglądy na przykład na temat fizyki i realizowanych programów nuklearnych, co nie przeszkadza należeć do odmiennych wspólnot religijnych i etnicznych. Tak więc wszyscy należymy do tej samej cywilizacji, wszystkich nas trapi problem konsumpcjonizmu, zawłaszczenia przez niebezpieczny konsumeryzm, problem ocieplenia klimatu, czystości powietrza, zmniejszających się zasobów wody pitnej, rosnących lawinowo odpadów itp.

W kontekście powyższego uważam, że z edukacyjnego punktu widzenia kreującego paradygmat współistnienia kultur, mamy jedną cywilizację globalną, co 
wyraźnie uświadomiła nam pandemia COVID-19. Mające miejsce różnego rodzaju konflikty religijne, etniczne i narodowościowe nie spowodują separacji, a wręcz przeciwnie, jak pisze Harari (2018, s. 148): „Sprawią, że będziemy coraz bardziej wzajemnie od siebie zależni. Choć ludzkości bardzo daleko do ustanowienia harmonijnej społeczności, wszyscy jesteśmy członkami jednej hałaśliwej globalnej cywilizacji”.

W globalnym modelu współistnienia kultur za wartość wiodącą uważam nabywanie umiejętności adaptacyjnych w wielokulturowym świecie, które w efekcie prowadzą ku uświadomieniu istoty funkcjonowania pogranicznego i potrzeby nabywania kompetencji międzykulturowych. Ostatecznym efektem w proponowanym modelu jest zrównoważony system tożsamościowy, który postrzegam i analizuję w trzech zakresach (dziedziczonym, indywidualnie kształtowanym i społecznie realizowanym), w trzech czasookresach (przeszłość, teraźniejszość, antycypowana przyszłość) i wielu wymiarach tożsamości indywidualnej (biologicznej, psychicznej, ekonomicznej, kulturowej, intelektualnej, egzystencjalnej itp.) oraz wielu wymiarach tożsamości społeczno-kulturowej (rodzinnej, familijnej, parafialnej, lokalnej, regionalnej, religijnej, etnicznej, narodowościowej, państwowej, kontynentalnej, globalnej).

\section{ADAPTACJA JAKO PIERWSZY ETAP NABYWANIA ŚWIADOMOŚCI FUNKCJONOWANIA POGRANICZNEGO}

Od zarania ludzkości człowiek mniej lub bardziej świadomie kreował paradygmat współistnienia kultur, przeżywając szok kulturowy w kontaktach z reprezentantami innych kultur, operując całą gamą emocji i zachowań. Doświadczał poczucia bezradności, frustracji, niechęci, zagubienia i wyobcowania, jak też zrozumienia, uznania, podziwu, szacunku i aprobaty. Problemem był i jest przebieg procesu adaptacji, funkcjonujące mity, stereotypy i uprzedzenia w kontaktach i interakcjach z reprezentantami innych kultur, reakcje na odmienne zasady, wartości i wzorce, uwarunkowania procesu niwelowania lęków, uprzedzeń i stereotypów czy też ich rozwijania i pomnażania.

Sądzę, że możemy mówić o wielowiekowym wpisywaniu się migracji w paradygmat globalnego współistnienia kultur. Można opisywać człowieka zamieszkującego ziemię jako tubylca i jako wędrowca. Wędrowiec, nomada, zdążając przed siebie, sens swojej egzystencji widzi w kierunku, ku któremu zmierza, a nie w miejscu, w którym się urodził i w którym przebywa. Przekraczając siebie i granice, kreuje fenomen pograniczności, sytuując się na granicy, między granicami 
i poza nimi. Należałoby zapytać, czy jest świadomy, dokąd i po co zmierza, czy przewiduje skutki, konsekwencje zmiany miejsca. Tubylec, mieszkaniec określonej przestrzeni, posiada swoje stałe miejsce, skąd patrzy na świat, szanując tradycję, historię, losy, przeżycia związane z daną przestrzenią.

Uważam, że szczególnie istotnym obecnie problemem egzystencjalnym jest jednoczesne bycie zakorzenionym i wędrowcem. Unia Europejska powstała, aby oswajać się z różnicami bliskimi nam cywilizacyjnie. Różnice kulturowe między Europejczykami ustawicznie poznajemy i uświadamiamy sobie ich specyfikę i wartość. Można powiedzieć, że osiągnięto sukces, to właśnie on spowodował napływ zbyt wielu imigrantów z Afryki i Bliskiego Wschodu. Szerokie otwarcie Europy spowodowało poważne kłopoty z ich zagospodarowaniem, adaptacją, nabywaniem świadomości pogranicznego funkcjonowania i z tym związanych kompetencji międzykulturowych. Europejski projekt przekraczania granic narodowych i kulturowych sprawdzał się przez wiele lat, zanim nie został zburzony rosnącą, niekontrolowaną falą uchodźców i imigrantów. Obecnie wiadomo, że niemożliwe jest pozostanie wiernym europejskim wartościom wielokulturowości, poprawności politycznej i relatywizmu kulturowego. Problem moim zdaniem tkwi w oczekiwaniu na realizację praw człowieka z rozszerzeniem ich na prawa socjalne, przy jednoczesnym braku uznania i szacunku do wzorów, norm i wartości gospodarzy. Nie oczekując od migrantów rezygnacji z własnych tradycji, winniśmy stwarzać warunki i oczekiwać świadomego uczestnictwa w procesie adaptacji do nowych warunków.

Znana jest koncepcja Johna Berry’ego (1997, 2017) przedstawiająca strategie działania imigrujących jednostek w wymiarze psychicznym, społeczno-kulturowym, ekonomicznym, w relacji do przyjmującego społeczeństwa. Uważam, że w każdym przypadku istotą jest wypracowanie zrównoważonego systemu interakcji, który pozwalałby kultywować kulturę odziedziczoną i przyjmować oraz szanować wartości społeczności przyjmującej. Stąd konieczne jest zauważenie potrzeby zachowania własnych tradycji oraz analiza czynników sprzyjających bądź hamujących dostosowywanie się jednostek i grup do nowych warunków, organizowanie warunków i sytuacji sprzyjających wykraczaniu poza krąg własnej grupy kulturowej.

Nabycie przez imigranta umiejętności funkcjonowania w nowym środowisku daje poczucie bezpieczeństwa i równocześnie umożliwia uczestnictwo w rodzimej wspólnocie kulturowej. Korzystają z powyższego obydwie strony, ucząc się wzajemnie od siebie, redukując konflikty, wdrażając do koncyliacyjnego rozwiązywania problemów, wdrażając do kooperacji i wymiany. Efektywna adaptacja to adaptacja wielowymiarowa o charakterze dwustronnym, gdzie będzie nastę- 
powało wzajemne zauważanie siebie, poznawanie się, tolerowanie, współpraca i współdziałanie. Umożliwi to ukazanie kultury społeczeństwa przyjmującego i zobligowanie przybyszów do zaprezentowania rodzimej kultury, możliwość jej prezentacji kulturze przyjmującej. Uważam, że bez wejścia w proces akulturacji adaptacja będzie powierzchowna. Jedynie proces dwustronny może przyczynić się do działań związanych z potrzebą i motywacją podnoszenia kwalifikacji, adaptacji członków rodziny, edukacji szkolnej dzieci oraz wielu innych form interakcji w nowym środowisku. Oczywistym są trudności w procesie adaptacji w wymiarze językowym, religijnym, szerzej kulturowym, orientowaniu się w sferze symbolicznej i aksjologicznej kraju emigracji, wypracowaniu w tym zakresie konsensusu między kulturą własną i obcą, niwelowaniu uprzedzeń i stereotypów, lęków i obaw związanych z marginalizacją i stygmatyzacją. Ważne więc w procesie adaptacji są nawiązane i utrzymywane kontakty społeczne, powstałe więzi sąsiedzkie i zawodowe, działalność na rzecz wspólnoty lokalnej itp.

Tak rozumiany i kształtowany proces adaptacji ma szanse kształtować idee dialogu z umiejętnością pogranicznego funkcjonowania i kształtowania pokoju, co stało się jednym z najważniejszych zobowiązań edukacyjnych na XXI wiek. „Ta problematyka urasta do wymiarów symbolicznych i zasługuje na naszą baczną uwagę, od dawna bowiem przezwyciężyliśmy powierzchowne hasła upolitycznionej „walki o pokój”, szukamy natomiast edukacyjnych sposobów, aby zgodnie ze słowami C.K. Norwida „czynić pokój” (Wojnar, 2000, s. 110). Uważam, że mieszkańcy Europy, których cywilizacja kształtowała się na bazie judaizmu, chrześcijaństwa, filozofii greckiej i prawa rzymskiego, ukształtowali swoisty fenomen pogranicza kultur, na co zwraca uwagę Olga Tokarczuk (2019, s. 12), wskazując: „(...) Moja energia bierze się z ruchu”. Podkreśla, co uważam za szczególnie istotne w procesie adaptacji do nowych warunków i kształtowania świadomości pogranicza: „Nie chciałam mieć stałych poglądów, byłyby niepotrzebnym bagażem. (...) Byłam świadkiem dziwnego zjawiska, które zachodziło w mojej głowie: im więcej znajdowałam argumentów »za«, tym więcej przychodziło mi do głowy tych »przeciw «, a im bardziej przywiązywałam się do tych pierwszych, tym bardziej ponętne stawały się te drugie” (Tokarczuk, 2019, s. 19-20).

\section{3. ŚWIADOMOŚĆ POGRANICZY UKIERUNKOWUJĄCA KU NABYWANIU KOMPETENCJI MIĘDZYKULTUROWYCH}

Uważam, że współczesny człowiek coraz częściej funkcjonuje na pograniczach innych kultur, coraz częściej świadomie selekcjonuje i synkretyzuje. „Nieupra- 
wianie terenu »pomiędzy « dopuszcza instrumentalne traktowanie kwestii kultury (i kultur), ignorancję i powrót do kategorii zużytych, "przeterminowanych« i z tego powodu szkodliwych” (Czajka, 2012, s. 13).

Świadomość, jako najwyższy poziom rozwoju psychicznego, charakterystyczny dla człowieka, jest z jednej strony związana z poczuciem kultywowania wartości i norm przejętych od własnej grupy kulturowej i deklarowania przynależności do niej, z drugiej zaś z potrzebą i niejednokrotnie koniecznością doświadczania i poznawania przedstawicieli reprezentujących odmienne grupy językowe, etniczne, narodowe, kulturowe czy religijne. Stąd w metaforycznej wizji pogranicze traktuję jako obszar przenikania, zapożyczania i jednocześnie obrony i ochrony odziedziczonych zasad i wartości. Jest to obszar zróżnicowań, który pozwala uświadomić odrębności i podobieństwa, porównywać, odkrywać, negocjować, prowadzić dialog. Świadomość pogranicznego funkcjonowania winna charakteryzować się umiejętnością interakcji, korzystania z treści nowej kultury bytowania. W efekcie ukierunkowujemy się ku świadomości społecznej interpretowanej jako zbiór pojęć, wyobrażeń, przekonań, ocen, typowych dla ludzi w pewnym środowisku, który ulega wzmocnieniu dzięki temu, że jest postrzegany jako wspólny z innymi (Sztompka, 2002, s. 28-29).

Wdrażanie do potrzeby świadomego pogranicznego funkcjonowania migranta traktuję jako wyzwanie edukacyjne w kontekście wyzwalania idei, celów, poglądów, przekonań i postaw wykraczających poza określane socjalizacją i enkulturacją granice. To przekraczanie łączę między innymi z naturalną ciekawością poznawczą, potrzebą poznania i wzbogacania się odrębnością kulturową, możliwością porównań i odniesień i tym samym zauważania i nadawania wartości odziedziczonym normom i wzorom kulturowym. Stąd w procesie edukacji, w każdym z krajów naszego globu ziemskiego, bez względu na nasze miejsce życia i pracy, stajemy wobec istotnego problemu: jak socjalizować, uczyć i wychowywać dzieci, młodzież, dorosłych, jak wspierać w rozwoju, aby trwać jako naród i państwo, ze swoistymi wartościami i jednocześnie rozumieć kontynentalne i globalne wyzwania i uczestniczyć w realizacji zadań z tymi wyzwaniami związanych?

Jeżeli chcemy, aby demokracja, prawa człowieka i kapitalizm wolnorynkowy dominowały w większości państw globu ziemskiego, to winniśmy nabywać umiejętności funkcjonowania we wspólnotach kontynentalnych i globalnych, dbać o wartości uniwersalne, świadomie i odpowiedzialnie działać na rzecz utrzymania pokoju, zapanować nad takimi zjawiskami jak dyktatura, terroryzm, kwestionowanie równości i wolności. Margit Stein (2008, s. 276-294), wskazując na zmianę i pluralizm wartości w wyniku procesu globalizacji, zwraca uwagę, że młode pokolenie ma utrudnione dojrzewanie z powodu wielu zmian, które nie ograniczają się do jednej 
narodowości, obejmują cały świat. Przedstawia, odwołując się do literatury przedmiotu, wiele zjawisk i procesów gospodarczych, technologicznych, ekologicznych, politycznych i innych, które w przyszłości będą siłą napędzającą społeczeństwa.

W kontekście powyższego chciałbym zauważyć w działaniach edukacyjnych dwie główne funkcje: socjalizacyjną i enkulturacyjną oraz wyzwalającą z socjalizacji i enkulturacji. Jeżeli pierwsza uspołecznia oraz ukulturalnia i czyni człowieka członkiem społeczności ludzkiej z wszystkimi tego uspołecznienia i kulturalizacji konsekwencjami, to druga sprowadza się do wyzwalania spod dominacji społecznej i możliwego zawłaszczenia kulturowego, do wykraczania poza status quo, do wyzwalania działań twórczych, podejmowania inicjatyw, rozwijania własnego sprawstwa, poszukiwania nowych jakości, nowych form realizacji ról, czyli do świadomego funkcjonowania pogranicznego. To powoduje rozszerzanie potencjału, zwiększanie zasobu i możliwości edukacyjnych, kształtuje świadomość potrzeby uwolnienia się od istniejących podziałów, od reagowania na coś i na kogoś lękiem, uprzedzeniem, stereotypowym myśleniem. Tym samym niniejszy fenomen świadomości pogranicza jest związany z kategorią „oporu”, niedopuszczaniem do marginalizacji, wykluczania, stygmatyzacji, ochroną i obroną praw do samostanowienia, realizacją wolności, godności i odpowiedzialności, wyzwolenia się spod wyznaczonych granic. Na bazie wartości własnej kultury istnieje naturalna możliwość poznania innej kultury, możliwość dokonywania porównań własnego dziedzictwa kulturowego z dziedzictwem innych grup, gdyż życie w kulturze mierzy się zdolnością bycia „pogranicznego”, „na progu”, w kontekście i wobec granicy, która stawia przed nami konieczność odpowiedzi na pytania - gdzie, jak i dlaczego warto być (Witkowski, 1990, s. 52).

Nie jest przypadkiem, że w wizjach nowoczesnych społeczeństw przebija się idea demokracji jako celebrowania różnicy, jako stylu dopuszczania do głosu inności. Na pograniczu powstaje potrzeba godzenia racji, tradycji, prawdy mojej, ale i Innego. W tym kontekście fenomen pogranicza kultur w obecnych warunkach wielokulturowości staje się miejscem tworzenia nowego człowieka o specyficznej świadomości społeczno-kulturowej, świadomości ustawicznie wzbogacającej się w dialogu wewnętrznym i zewnętrznym (Sobecki, Misiejuk, Muszyńska, Bajkowski, red., 2019). Jest to proces skomplikowany, bowiem „(...) granice kulturowe »my-oni« ulokowane na zewnątrz nas są przedłużeniem takich granic w nas. To ukryty wymiar naszej tożsamości” (Krzysztofek, 1999, s. 35).

Uważam, że świadomość pograniczy wyposaża człowieka w elementy aksjologiczne i etyczne. Dla filozofii dialogu wartościowymi aspektami jest dostrzeganie, szacunek i szczera chęć zrozumienia drugiego człowieka i odpowiedzialność za Innego, co należy traktować w kategoriach tolerancji i nakazu etycznego. Ks. Józef 
Tischner (1995, s. 47) pisał, że człowiek prowadzi „grę o odpowiedzialność” i albo przyjmuje ją, albo odrzuca. Powołując się na tezę Emmanuela Lévinasa (1994), wskazywał, że odpowiedzialność żyje w stanie uśpienia w każdym z nas, a wyzwolić ją może próba nawiązania kontaktu, wejście w interakcję z Innym. Stąd kompetencje międzykulturowe traktuję jako umiejętności wyższego rzędu, które osiąga się poprzez doświadczanie interakcji w komunikacji z innymi i dokonywane na tej bazie refleksje. Dlatego w literaturze anglojęzycznej często zastępowane są określeniem „zasoby”. Wiąże się je z uprawnieniami do działania i odpowiedzialności w trakcie realizacji zadań. Analizuje się jako proces przygotowania do realizacji określonych zadań, przygotowania do pełnienia funkcji, świadomego i twórczego podejmowania działań na bazie wiedzy, doświadczeń, nabytych umiejętności, ukształtowanych postaw itp. Podstawowe znaczenie nadaje się zasobom, potencjałowi podmiotu i wskazuje się na jego zdolności i możliwości do podejmowania i wykonywania określonych zadań (Męczkowska, 2003, s. 693). Problemem jest interpretacja kompetencji w perspektywie statycznej, adaptacyjnej, behawioralnej, związanej z dyspozycjami do instrumentalnego działania, i w perspektywie dynamicznej, związanej z autokreacją, twórczością, transgresją. Kompetencje międzykulturowe traktuję jako istotne wyzwanie dla współczesnych społeczeństw wobec dwóch mechanizmów społecznych: dzielenia mieszkańców makro-, mezo- i mikrostruktur globu ziemskiego na „swoich” i „obcych” oraz potrzebę i konieczność współpracy z reprezentantami innych kultur. Stąd posiadane przez każdego członka globu ziemskiego kompetencje (indywidualne, społeczne, zawodowe, strategiczne i wiele innych) powinniśmy odnosić do relacji i komunikacji międzykulturowej. Z powyższym związana jest potrzeba nabywania świadomości, że wartości, normy, wzorce i symbole posiadają charakter względny, warunkowany przynależnością do określonego kręgu kulturowego. Warunki zróżnicowania kulturowego i dylematy z tym związane spowodowały pojawienie się nowego imperatywu ukierunkowanego na rozszerzenie perspektyw myślenia „(...) lepszego rozumienia innych, lepszego rozumienia świata; konieczność wzajemnego zrozumienia, pokojowej wymiany idei, czy wręcz jedności. Tego najbardziej brakuje naszemu światu” (Delors, 1998, s. 17).

Funkcjonując w warunkach globalizacji, stajemy przed wyzwaniem kształtowania warunków do nabywania kompetencji międzykulturowych, między innymi poprzez komunikację międzykulturową i edukację międzykulturową. Jeśli chcemy korzystać z kultury wytworzonej w różnych społeczeństwach, porozumiewać się z reprezentantami różnych kultur, migrantami, turystami, menadżerami firm zagranicznych, współpracować naukowo i edukacyjnie, to powinniśmy zadbać o rozwijanie kompetencji międzykulturowych. Katarzyna Gajek (2011, s. 209), 
przedstawiając różne ujęcia rozumienia kompetencji międzykulturowych, zwraca uwagę na ich komplementarność wobec siebie. „Wyłania się z nich wielowymiarowy obraz, na który składają się czynniki niższego i wyższego stopnia. Na poziomie podstawowym znajdują się wiedza (znajomość historii, języka, poglądów na świat, savoir-vivre’u, tradycji, ról społecznych itp.), umiejętności (umiejętność słuchania, decentracji, rozwiązywania problemów, refleksyjność itp.) oraz motywacja (samoświadomość dotycząca aspiracji, źródła motywacji, własnego stylu komunikowania itp.). Na poziomie zaawansowanym zaś sytuują się takie wspomniane czynniki, jak kreatywność, krytycyzm i autonomia moralna”. Winniśmy więc $\mathrm{w}$ działaniach edukacyjnych zadbać nie tylko o treningi, szkolenia i kursy, ale o umiejętności i postawy dialogiczne, gdyż: „(...) Obecnie kompetencje międzykulturowe są ważniejsze niż kiedykolwiek, pozwalają bowiem dostrzec i poznać przyczyny niektórych najbardziej uciążliwych problemów, nękających współczesne społeczeństwa. U podstaw takich zjawisk jak dyskryminacja, rasizm, mowa nienawiści leżą właśnie różnice kulturowe, społeczno-kulturowe, etniczne i inne" (Brotto, Huber i in., 2014, s. 5).

Mając na uwadze powyższe, chciałbym podkreślić, że na wielu polskich uczelniach wyższych realizowane są projekty przygotowujące nauczycieli do pracy w roli mediatorów międzykulturowych w ramach zajęć obligatoryjnych i fakultatywnych oraz inicjatyw realizowanych we współpracy z instytucjami i organizacjami pozarządowymi. Zajęcia te prowadzone są w formie warsztatów, ćwiczeń i wykładów, łącząc w sobie elementy merytoryczne (dostarczanie i poszerzanie wiedzy niezbędnej do życia/pracy w środowiskach wielokulturowych) z elementami rozwijania świadomości, praktycznych umiejętności i postaw. Warto zwrócić uwagę na wartościowe monografie naukowo-metodyczne dotyczące kształtowania międzykulturowych kompetencji komunikacyjnych w procesie uczenia się języka polskiego jako obcego dzieci cudzoziemskich. Między innymi monografia Anny Młynarczuk-Sokołowskiej i Katarzyny Szostak-Król (2016) prezentująca uczenie się języka polskiego dzieci różnych narodowości.

\section{KU ZRÓWNOWAŻONEMU SYSTEMOWI TOŻSAMOŚCIOWEMU}

Uczestnicząc twórczo w procesie kształtowania się zrównoważonego systemu tożsamościowego, dokonującego się w kontekście procesów migracyjnych, należałoby ustawicznie formułować pytanie: jak w warunkach mobilności społecznej system tożsamościowy koordynuje mechanizmy społecznego różnicowania oraz integracji w ramach konfiguracji aksjonormatywnych społeczeństw wielokulturowych? 
Oderwanie się od własnej kultury, środowiska familijnego i lokalnego, w którym się wzrastało i rozwijało, inicjuje proces zmian dotyczących fundamentalnych kwestii dla tożsamości człowieka migrującego. Kształtująca się tożsamość międzykulturowa, w odróżnieniu od kulturowej, jest wynikiem korzystania w rozwoju z ofert innych kultur, czerpania i zapożyczania z nich, aktywnego i twórczego udziału w procesie akulturacji poprzez dokonywanie selekcji, włączanie pewnych elementów kulturowych, rezygnowanie z innych itd. Z pewnością wielokulturowa Europa i świat potrzebują obecnie zaistnienia w człowieku i funkcjonowania w nim wielu kultur, a tym samym tolerancji, akceptacji i uznania wobec nowego człowieka charakteryzującego się dynamiczną tożsamością międzykulturową i transkulturową, człowieka reprezentującego i szanującego w sobie jednocześnie, obok kultury odziedziczonej, kultury nabywane w wyniku ich doświadczania, zmiany miejsca życia i pracy.

W obecnych warunkach wielokulturowości połączonych z dynamicznymi przemianami społeczno-politycznymi, ekonomicznymi, kulturowymi, komunikacyjnymi i wieloma innymi, następuje ustawiczne redefiniowanie przynależności i kolejne identyfikacje, aż do globalnych odniesień (Nikitorowicz 2017, 2020). Zjawisko to jest wynikiem odpowiedzialnego i wolnego w wyborze samookreślania się jednostki, świadomego przyjęcia na siebie zadań rozwojowych w określonej przestrzeni społeczno-kulturowej, usytuowania się w relacjach z innymi ludźmi, określania hierarchii wartości, zasad i norm postępowania. W warunkach współczesnej wielokulturowości i migracji lojalność wobec wartości rodzimej grupy może być rozbudowywana zróżnicowanymi systemami aksjologicznymi i teleologicznymi, poszerzana w kontekście odbioru całej gamy ofert i propozycji świata globalnego. W efekcie nakazuje to człowiekowi ustawicznie pytać o tożsamość, jej wymiary, integrację, podejmować wyzwania, aby odnaleźć się w bogatym w różnorodność świecie, dynamicznej i zmiennej rzeczywistości społeczno-kulturowej. Stąd tożsamość w warunkach ustawicznych migracji traktuję jako twórczy wysiłek podmiotu łagodzący napięcia i sprzeczności pomiędzy elementami stałymi, odziedziczonymi, nadanymi przez fakt urodzenia w określonym miejscu, zakorzeniającymi w określonej przestrzeni rodzinno-familijnej, lokalnej, parafialnej, regionalnej, etnicznej, narodowej, a pamięcią o nich, tych wymiarach-przestrzeniach, oraz nabywaną tożsamością społeczno-kulturową w nowych warunkach, w nowym miejscu osiedlenia się, życia i pracy.

Tak kreowana tożsamość, jako twórczy wysiłek korzystania z potencjału odziedziczonego kultury rodzimej, w połączeniu z pamięcią o doświadczanych przestrzeniach tej kultury oraz w połączeniu ze świadomym i odpowiedzialnym postrzeganiem siebie w nowych rolach, w nowym miejscu globu ziemskiego, 
w nowych strukturach państwowych, ukierunkowuje ku globalnemu paradygmatowi współistnienia kultur. W efekcie pozwala kształtować zrównoważony system tożsamościowy, w którym występują, oddziałując na siebie, trzy równorzędne zakresy tożsamości (dziedziczona, indywidualnie kształtowana i społecznie realizowana), trzy czasookresy (przeszłość, teraźniejszość, antycypowana przyszłość) i różne wymiary tożsamości indywidualnej (biologiczna, psychiczna, ekonomiczna, kulturowa, intelektualna, egzystencjalna itp.), jak też różne wymiary tożsamości społeczno-kulturowej (rodzinna, familijna, parafialna, lokalna, regionalna, religijna, etniczna, narodowościowa, państwowa, kontynentalna, globalna).

We wskazanym wyżej modelu chciałbym zwrócić uwagę na nieświadome przyswajane dziedzictwa kulturowego jako wartość stałą, rdzeń tożsamościowy (pestkę tożsamościową). Przyjęcie i akceptacja w kulturze rodzinno-lokalnej rozpoczyna proces jej kreowania się, stąd niezbędne jest wsparcie i zapewnienie poczucia bezpieczeństwa w rozwoju. Od tego, jakie wsparcie i zabezpieczenie rozwoju otrzymała jednostka, w jakim kontekście społeczno-politycznym realizowała się, będzie zależeć jej realizacja w nowych rolach, jej relacje z innymi, ukierunkowanie rozwoju i kształtowanie się tożsamości ku homogeniczności lub ku heterogeniczności, ku asymilacji lub ku integracji itp. Uważam, że tożsamość migranta wzbogacana jest zawsze dobrą lub złą pamięcią, ale jak się rozwija, trwa i ukierunkowuje we wskazanych trzech zakresach, czasookresach, jakie wymiary stają się dominującymi, a jakie podrzędnymi, uzależnione jest od aktywnego, świadomego i odpowiedzialnego uczestnictwa w procesie edukacyjnym. To edukacja, rozumiana jako ogół działań, procesów i warunków sprzyjających rozwojowi człowieka prowadzi do lepszego rozumienia siebie i interakcji ze światem, umożliwia kształtowanie postaw i potrzeb, kontrolę zachowań, emocji, sprawstwo, odpowiedzialność itp.

\section{UWAGI KOŃCOWE}

W złożonym, dynamicznym, niekończącym się procesie kreowania tożsamości człowieka cywilizacji globalnej szczególne zadania przypisałbym edukacji międzykulturowej, poczynając od poddawania analizie i wartościowaniu treści odziedziczonej kultury z jednoczesnym wdrażaniem do zauważania innych kultur, do aktywnego, twórczego uczestnictwa w nich. Treści wynikające z tradycji nie mogą być ignorowane, jednak w rozwoju człowieka i jego kultury istotna jest umiejętność funkcjonowania pogranicznego, podejmowane interakcje i doświadczanie komunikacji z innymi w różnych sferach życia. Stąd podstawą paradygmatu współistnienia kultur 
w obecnych warunkach ustawicznych migracji są fundamentalne prawa człowieka (do życia, wolności i własności). To wyznacza autonomię człowieka oraz granice tej autonomii. Ktoś, kto je narusza, wyłącza się spod ich obowiązywania, wystawia się na sankcje, które określa i przewiduje każda kultura, czyli pozbawienie wolności, odebranie własności, a nawet życia. Uprawnienia te tworzą warunki minimum dla istnienia i rozwoju człowieka i są immanentnie związane z podstawowymi wartościami humanistycznymi (prawdą, dobrem i pięknem).

Zakładając, że migracje były, są i będą, istotnym zadaniem edukacji jest kształtowanie świadomości w zakresie aktywnej adaptacji do nowych warunków, organizowanie warunków i sytuacji do nabywania umiejętności funkcjonowania pogranicznego, kompetencji międzykulturowych, ukazywanie złożonych losów ludzkich i tym samym uwrażliwianie na nie, niwelowanie uprzedzeń poprzez poznawanie i doświadczanie, kształtowanie postaw zauważania, poznawania, zrozumienia i porozumienia między ludźmi reprezentującymi różne kultury. Sądzę, że na różnym poziomie działań edukacyjnych można i należy ukazywać życiorysy rodzinne, na przykład takie jak przedstawione w książce Anny Kaszubskiej i Targan Nasordinovej (2016). Problemem, nad którym edukacja międzykulturowa ustawicznie pracuje, jest kwestia nabywania świadomości przez każdego członka globu ziemskiego, że gatunek ludzki różni się pochodzeniem, miejscem dziedziczenia i kształtowania się tożsamości, wychowaniem, wyznawaną religią itp. Historia przedstawiona w wyżej wskazanej pracy pozwala docenić życie, odnaleźć piękno i dobro, ułożyć od nowa priorytety i wyraźnie zobaczyć to, co naprawdę jest w procesie rozwoju tożsamości ważne. Przedstawione w niej przeżycia są przykładem zmian w świadomości, gdzie z jednej strony zauważamy szacunek do wartości i zasad odziedziczonej kultury, z drugiej zaś odpowiedzialność za zdrowie i życie dzieci i możliwość rozwoju w nowych warunkach. Ukazuje to, co obecnie w globalnym świecie wydaje się najistotniejsze, doświadczanie przyjaźni mimo barier kulturowych, a także nadzieję na lepsze jutro.

\section{Bibliografia}

Berry, J.W. (2017). Theories and Models of Acculturation. W: S.J. Schwartz, J.B. Unger (eds.), The Oxford Handbook of Acculturation and Health (s. 15-28). New York: Oxford University Press.

Berry, J.W. (1997). Immigration, Acculturation, and Adaptation. Applied Psychology, 46(1), s. 5-34.

Brotto, F., Huber, J., Karwacka-Vogele, K., Neuner, G., Ruffino, R., Teutsch, R. (2014). Kompetencje międzykulturowe dla wszystkich. Przygotowanie do życia w różnorodnym świecie. Warszawa: Ośrodek Rozwoju Edukacji. 
Czajka, A. (2012). Wstęp. W: A. Czajka (red.), Kultury świata w dialogu. Warszawa: Wydawnictwo UKSW.

Delors, J. (1998). Edukacja. Jest w niej ukryty skarb. Tłum. W. Grabczuk. Warszawa: Wydawnictwo UNESCO.

Gajek, K. (2011). Kompetencje międzykulturowe jako element kultury współczesnej organizacji - dylematy teorii i praktyki. Problemy Zarzqdzania, t. 9, 2(32).

Harari, Y.N. (2018). 21 lekcji na XXI wiek. Tłum. M. Romanek. Kraków: Wydawnictwo Literackie.

Huntington, S.P. (1998). Zderzenie cywilizacji i nowy kształt ładu światowego. Tłum. H. Jankowska. Warszawa: Wydawnictwo MUZA SA.

Kaszubska, A., Nasordinova, Z. (2016). 186 szwów. Z Czeczenii do Polski. Droga matki. Warszawa: EDIPRESSE.

Kawczyńska-Butrym, Z. (2009). Migracje. Wybrane zagadnienia. Lublin: Wydawnictwo UMCS.

Krzysztofek, K. (1999). Wielokulturowość, demokracja i rynek kultury. W: A. Sadowski, (red.), Pogranicze. Studia Społeczne, t. VIII (s. 7-27). Białystok: Wydawnictwo Uniwersytetu w Białymstoku.

Levinas, E. (1994). O Bogu, który nawiedza myśl. Kraków: Wydawnictwo Znak.

Męczykowska, A. (2003). Kompetencja. W: T. Pilch (red.), Encyklopedia pedagogiczna XXI wieku, t. II. Warszawa: Wydawnictwo Akademickie „Żak”.

Młynarczuk-Sokołowska, A., Szostak-Król, K. (2016). Zrozumieć Innego. Międzykulturowa kompetencja komunikacyjna w procesie uczenia się języka polskiego jako obcego. Białystok: Fundacja Dialog.

Nikitorowicz, J. (2017). Etnopedagogika w kontekście wielokulturowości o ustawicznie kształtującej się tożsamości. Kraków: „Impuls”.

Nikitorowicz, J. (2020). Edukacja międzykulturowa w perspektywie paradygmatu współistnienia kultur. Białystok: Wydawnictwo Uniwersytetu w Białymstoku.

Sobecki, M., Misiejuk, D., Muszyńska, J., Bajkowski, T. (red.). (2019). Człowiek pogranicza. Wyzwania humanistycznej edukacji. Białystok: Wydawnictwo Uniwersytetu w Białymstoku.

Stein, M. (2008). Solidarność i tolerancja w wychowaniu jako podstawa edukacji międzykulturowej. Komunikat z badań w Bawarii. W: J. Szurzykiewicz, M. Kulesza (red.), Integracja w świecie powszechnej migracji. Otwarte pytania pedagogiki społecznej. Warszawa: Wydawnictwo Uniwersytetu Warszawskiego.

Sztompka, P. (2002). Socjologia. Analiza społeczeństwa. Kraków: Wydawnictwo Znak. Tischner, J. (1995). Gra wokół odpowiedzialności. Kraków: Wydawnictwo Znak.

Tokarczuk, O. (2019). Bieguni. Kraków: Wydawnictwo Literackie.

Witkowski, L. (1990). W stronę edukacji (dla) pogranicza (pedagogiczne „Bachtinalia”). Kwartalnik Pedagogiczny, 4, s. 47-66.

Wojnar, I. (2000). Kształtowanie kultury pokoju zobowiązaniem edukacyjnym na XXI wiek. W: I. Wojnar, Humanistyczne intencje edukacji. Warszawa: Wydawnictwo Akademickie „Żak”. 